\title{
EVALUASI SISTEM DAN PROSEDUR PENERIMAAN PENDAPATAN ASLI DAERAH (PAD) KABUPATEN NABIRE
}

\author{
Ria A. Effendhi ${ }^{1}$, Jullie J. Sondakh ${ }^{2}$, Novi S. Budiarso ${ }^{3}$ \\ ${ }^{1,2,3}$ Fakultas Ekonomi dan Bisnis, Jurusan Akuntansi. Universitas Sam Ratulangi, Jl. Kampus Bahu Manado, \\ 95115, Indonesia
}

email: riaangel.ra94@gmail.com

\begin{abstract}
Regional Original Revenue (PAD) is the revenue earned by the region from sources within its own area which are levied according to the local regulations in accordance with the prevailing laws and regulations. The cash receipts system and procedures used in the scope of government are one of the most important parts in implementing local financial management, in an effort to increase the local revenue (PAD). The analytical method used is descriptive analysis, while evaluation of system and procedure is done by comparing between the concepts, theories and the rules in the implementation of the system and the procedure of receipt of PAD, especially with the provision of PERMENDAGRI No. 59. Based on this research, it is found that the acceptance system and procedures at the Nabire Regency Revenue Service have been conducted in accordance with Law No. 16 of 2000 and PERMENDAGRI No. 59 Year 2007.
\end{abstract}

Keywords: Systems and Procedures Receipts

\section{PENDAHULUAN}

Negara Kesatuan Republik Indonesia menyelenggarakan pemerintahan negara dan pembangunan nasional untuk mencapai masyarakat adil, makmur, dan merata berdasarkan Pancasila dan Undang-Undang Dasar Negara Republik Indonesia tahun 1945. Lahirnya Undang-Undang No. 22 Tahun 1999 tentang Pemerintahan Daerah menjadi bagian utama dari upaya reformasi birokrasi di Indonesia. Dengan Undang-Undang No. 22 Tahun 1999 ini pelaksanaan otonomi daerah yang sesungguhnya mulai diterapkan sesuai dengan sistem otonomi yang dianut dalam undang-undang ini yaitu, otonomi yang luas, nyata dan bertanggung jawab, dimana semua kewenangan pemerintah, kecuali bidang politik luar negeri, hankam, peradilan, moneter dan fiskal serta agama dan bidang-bidang tertentu diserahkan kepada daerah secara utuh, bulat dan menyeluruh, yang ditetapkan dengan peraturan pemerintah.

Pertimbangan mendasar dari terselenggaranya Otonomi Daerah (otoda) adalah ditinjau dari perkembangan kondisi didalam negeri yang mengindikasikan bahwa rakyat menghendaki keterbukaan dan kemandirian (desentralisasi). Selanjutnya peningkatan kemandirian Pemerintahan Daerah tersebut diharapkan dapat diraih melalui otonomi daerah. Umumnya faktor-faktor yang mempengaruhi keberhasilan otonomi daerah adalah kemampuan sumber daya manusia (aparat maupun masyarakat), sumber daya alam, kemampuan keuangan (financial), kemampuan manajemen, kondisi sosial budaya masyarakat, dan karakteristik ekologis. Misi utama Undang-undang nomor 33 tahun 2004 adalah bukan hanya melimpahkan kewenangan pembangunan dari pemerintah pusat ke pemerintah daerah, tetapi yang lebih penting adalah efisiensi dan efektifitas sumber daya keuangan. Penyelenggaraan urusan Pemerintahan Daerah dalam rangka pelaksanaan desentralisasi didanai Anggaran Pendapatan dan Belanja Daerah (APBD).

Pada dasarnya terdapat tiga pilar utama didalam mewujudkan good government, yaitu : Akuntabilitas, Transparasi, dan Partisipasi. Satu upaya nyata didalam penerapan prinsip-prinsip dasar good government ini adalah penyampaian laporan keterangan 
pertanggung jawaban keuangan pemerintahan daerah dengan standar akuntansi pemerintahan yang telah diterima secara umum. Karena sebagian besar otonomi daerah (tugas dan kewenangan mengatur daerah sendiri) diberikan kepada daerah otonom kabupaten dan daerah otonom kota atas dasar pertimbangan budaya, politik (demokrasi), dan ekonomi lokal. Proses penyusunan anggaran sektor publik umumnya disesuaikan dengan peraturan lembaga yang lebih tinggi yang didasarkan pada Undang-undang nomor 33 tahun 2004 tentang Perimbangan Keuangan Antara Pemerintahan Pusat dan Daerah, sehingga lahirlah tiga paket perundang-undangan, yaitu Undang-Undang nomor 17 tahun 2003 tentang Keuangan Negara, Undang-Undang nomor 1tahun 2004 tentang Perbendaharaan Negara, dan Undang-Undang nomor 15 tahun 2004 tentang Pemeriksaan Pengelolaan dan Tanggung Jawab Keuangan Negara, yang telah membuat perubahan mendasar dalam penyelenggaraan pemerintahan dan pengaturan keuangan, khususnya Perencanaan dan Pemerintahan Daerah dan Pemerintahan Pusat. Kemudian, keluar peraturan baru yaitu Peraturan Pemerintah nomor 58 tahun 2005 tentang Pengelolaan Keuangan Daerah dan Permendagri nomor 13 tahun 2006 (saat ini telah diubah dengan Permendagri nomor 59 tahun 2007) tentang Pedoman Pengelolaan Keuangan Daerah, yang akan menggantikan Kepmendagri nomor 29 tahun 2002. Pemerintah Kabupaten Nabire di bentuk berdasarkan Peraturan Pemerintah RI Nomor 52 Tahun 1996 sebagai wujud pemekaran Kabupaten Dati II Paniai yang dibagi menjadi 3 Kabupaten, yaitu : 1). Kabupaten Dati II Nabire dengan Ibukota Nabire, 2). Kabupaten Administrasi Paniai dengan ibukota Enarotali, dan 3). Kabupaten Administratif Puncak Jaya dengan ibukota Mulia.

Sistem dan prosedur penerimaan yang digunakan dalam ruang lingkup pemerintahan merupakan salah satu bagian terpenting dalam melaksanakan pengelolaan keuangan daerah, dalam upaya peningkatan Pendapatan Asli Daerah (PAD), yang didalamnya bersumber dari Pajak Daerah, Retribusi Daerah, Hasil pengelolaan kekayaan milik daerah yang dipisahkan, Lain-lain Pendapatan Asli Daerah yang sah, yang semuanya itu dikelola oleh Dinas pendapatan Daerah Kabupaten Nabire sebagai salah satu Satuan Kerja Perangkat Daerah (SKPD) yang berada dalam lingkungan Pemerintahan Kabupaten Nabire dengan Visinya yaitu Menjadikan Pendapatan Asli Daerah (PAD) sebagai kontribusi dominan dalam APBD Kabupaten Nabire dan Misinya yaitu meningkatkan Pendapatan Asli Daerah dalam rangka pelestarian otonomi daerah. Penelitian ini bertujuan untuk mengetahui Sistem dan Prosedur Penerimaan Pendapatan Asli Daerah di Kabupaten Nabire.

\section{TINJAUAN PUSTAKA Otonomi Daerah}

Menurut Vincent Lemius dalam Sujarweni (2015 : 230) bahwa otonomi daerah merupakan kebebasan untuk mengambil keputusan politik maupun administrasi, dengan tetap menghormati peraturan perundang-undangan. Meskipun dalam otonomi daerah ada kebebasan untuk menentukan apa yang menjadi kebutuhan daerah, tetapi kebetuhan daerah senantiasa disesuaikan dengan kepentingan nasional, ditetapkan dalam peraturan perundangundangan yang lebih tinggi.

\section{Asas Otonomi Daerah}

Adapun tiga asa otonomi daerah yang meliputi :

1. Asas desentralisasi yaitu penyerahan wewenang pemerintahan dari pemerintah kepada daerah otonom berdasarkan struktur NKRI.

2. Asas dekosentrasi yaitu pelimpahan wewenang dari pemerintah kepada gubernur sebagai wakil pemerintah dan atau perangkat pusat daerah.

3. Asas tugas pembantuan yaitu penugasan oleh pemerintah kepada daerah dan oleh daerah kepada desa dalam melaksanakan tugas tertentu dengan disertai pembiayaan, 
sarana, dan prasarana serta sumber daya manusia dengan kewajiban melaporkan pelaksanaannya dan mempertanggungjawabkan kepada yang berwenang.

\section{Ruang Lingkup Keuangan Daerah}

Menurut Peraturan Menteri Dalam Negeri No.13 Tahun 2006 Pasal 2 tentang ruang lingkup keuangan daerah adalah sebagai berikut:

1. Hak daerah untuk memungut pajak daerah dan retribusi daerah serta melakukan pinjaman;

2. Kewajiban daerah untuk menyelenggarakan urusan pemerintahan daerah dan membayar tagihan pihak ketiga;

3. Penerimaan daerah;

4. Pengeluaran daerah;

5. Kekayaan daerah yang dikelola sendiri atau oleh pihak lain berupa uang, surat berharga, piutang, barang, serta hak-hak lain yang dapat di nilai dengan uang, termasuk kekayaan yang di pisahkan pada perusahaan daerah; dan

6. Kekayaan pihak lain yang dikuasai oleh pemerintah daerah dalam rangka penyelenggaraan tugas pemerintah daerah dan/atau kepentingan umum.

\section{Sistem Akuntansi Keuangan Daerah}

Menurut Mashun, Firma dan Purwanugraha (2015:102) sistem akuntansi keuangan daerah mengatur tentang prosedur pencatatan transaksi melalui proses jurnalisasi, menetapkan format buku jurnal, buku besar, dan buku pembantu serta menetapkan kebijakan akuntansi pemerintah daerah.

\section{Tujuan Kerangka Konseptual Akuntansi Pemerintahan}

1. Penyusunan standar akuntansi pemerintahan.

2. Penanganan masalah akuntansi yang belum diatur dalam starndar akuntansi pemerintahan.

3. Pemberian opini oleh auditor tentang apakah laporan keuangan disusun sesuai dengan standar akuntansi pemerintahan.

4. Penafsiran informasi yang disajikan pada laporan keuangan pemerintahan oleh para pengguna.

\section{Sistem dan Prosedur Akuntansi Keuangan Daerah}

Sistem dan prosedur akuntansi yang terdapat dalam pemerintah daerah meliputi :

a. Sistem dan Prosedur penerimaan kas

b. Sistem dan Prosedur pengeluaran kas

c. Sistem dan prosedur akuntansi selain kas

d. Sistem dan prosedur akuntansi aset

\section{Sumber-sumber Pendapatan Daerah}

Menurut UU RI No. 17 Tahun 2003 Tentang Keuangan Daerah menyebutkan bahwa Pendapatan daerah adalah hak pemerintah daerah yang diakui sebagai penambah nilai kekayaan bersih.Pada umumnya APBD suatu daerah didominasi oleh sumbangan pemerintahan pusat dan sumbangan lain-lain, yang diatur dengan peraturan perundangundangan.Menurut PP Nomor 58 Tahun 2005 tentang Pengelolaan Keuangan Daerah, pada pasalnya yang ke 20 menyatakan bahwa APBD merupakan satu kesatuan yang terdiri dari: a. pendapatan daerah; b. belanja daerah; dan c. pembiayaan daerah. Pendapatan daerah sebagaimana dimaksud dalam Pasal 20 ayat (1) huruf a terdiri atas: a. Pendapatan Asli Daerah (PAD); b. Dana Perimbangan; dan c. Lain-lain pendapatan daerah yang sah. 


\section{Pajak Daerah}

Menurut Prof. Dr. Rochmat Soemitro, S. H dalam Mardiasmo (2016 : 5) pajak adalah iuran rakyat kepada kas Negara berdasarkan undang-undang (yang dapat dipaksakan) dengan tiada mendapat jasa timbal (kontraprestasi) yang langsung dapat ditunjukkan dan yang digunakan untuk membayar pengeluaran umum.

Dapat disimpulkan bahwa pajak memiliki unsur-unsur sebagai berikut :

1. Iuran Rakyat kepada Negara.

Yang berhak memungut pajak hanyalah negara. Iuran tersebut berupa uang ( bukan barang),

2. Berdasarkan undang-undang.

Pajak di pungut berdasarkan atau dengan kekuatan serat aturan pelaksanaannya.

3. Tanpa jasa timbal atau kontraprestasi pembayaran negara yang secara langsung dapat ditunjuk. Dalam pembayaran pajak tidak dapat ditunjukkan adanya krontraprestasi individual oleh pemerintah.

4. Digunakan untuk membiayai rumah tangga negara, yakni pengeluaran-pengeluaran yang bermanfaat bagi masyarakat luas.

\section{METODE PENELITIAN}

3.1. Jenis dan sumber data

Jenis penelitian yang digunakan penulis adalah penelitian deskriptif, yang dilakukan dengan cara mengumpulkan data yang berhubungan dengan permasalahan yang dihadapi. Data merupakan keterangan - keterangan yang diperoleh dari penelitian atau melalui referensi - referensi untuk mengetahui Sistem dan prosedur penerimaan pendapatan asli daerah Kabupaten Nabire. Sumber data dalam penelitian ini adalah sumber data sekunder. Sumber data sekunder merupakan sumber yang tidak langsung memberikan data kepada pengumpul data. Menurut Sujarweni (2014:6) Sumber data adalah subjek dari mana asal data penelitian itu diperoleh. Data Sekunder : Data yang didapat dari catatan, buku, majalah berupa laporan keuangan publikasi perusahaan, laporan pemerintah, artikel, buku-buku sebagai teori, majalah dan lain sebagainya. Data yang diperoleh dari data sekunder ini tidak perlu diolah lagi.

\subsection{Teknik Pengumpulan Data}

Teknik pengumpulan data dalam penelitian ini adalah berdasarkan teknik pengumpulan data menurut Ibrahim (2015 : 80) yaitu, observasi dan dokumentasi. Teknik pengumpulan data dilakukan dengan cara sebagai berikut:

1. Observasi, metode pengumpulan data dengan melakukan pengamatan langsung maupun tidak langsung terhadap aktivitas yang berhubungan dengan sistem dan prosedur penerimaan untuk PAD pada Dinas Pendapatan Daerah Kabupaten Nabire.

2. Dokumentasi, teknik pengumpulan data melalui pengumpulan bahan-bahan tertulis berupa buku-buku, data-data yang tersedia dan laporan-laporan yang relevan dengan objek penelitian untuk mendukung data yang sudah ada.

\subsection{Metode analisis Data}

Berdasarkan metode penelitian yang dilakukan, penelitian dapat di klasifikasikan menjadi penelitian deskriptif, penelitian korelasional, penelitain kasual komparatif, dan penelitian eksperimental. Metode analisis dalam penelitian ini menggunakan metode analisis deskriptif, yaitu suatu metode pembahasan masalah yang sifatnya menguraikan, menggambarkan, dan membandingkan suatu data atau keadaan serta menerangkan suatu keadaan sedemikian rupa agar dapat dianalisis sehingga memberikan informasi deskriptif yang akan menjawab pertanyaan dalam masalah. 


\section{HASIL ANALISIS DAN PEMBAHASAN}

Kabupaten Nabire merupakan salah satu wilayah di Provinsi Papua dari total 29 Kabupaten/kota, yang terhampar di seputar "Leher Burung" Pulau Papua, dengan visi Kabupaten Nabire yaitu "Membuka isolasi daerah demi terwujudnya masyarakat Nabire yang berwawasan keberagaman, berkeadilan sejahtera dan mandiri secara berkelanjutan dengan salah satu misinya yaitu meningkatkan kapasitas dan kapabilitas aparatur kelembagaan melalui penerapan tata kelola pemerintah yang baik dan bersih yang berorientasi pada pembangunan berkelanjutan serta meningkatkan kualitas sumber daya manusia yang sehat, berilmu berbudaya dan berdaya saing serta berwawasan lingkungan. Berdasarkan hasil proyeksi penduduk pada tahun 2015, jumlah penduduk Kabupaten Nabire sebanyak 140.178 jiwa.

Dengan diberlakukannya Undang-Undang No. 32 Tahun 2004 tentang Pemerintah Daerah yang lebih menekankan aspek desentralisasi yang diberikan dalam wujud otonomi daerah yang luas, nyata dan bertanggung jawab, maka dalam pelaksanaan yang berkaitan dengan otonomi daerah Kabupaten Nabire dapat dijelaskan dengan 2 aspek, yaitu : 1). Aspek Politik, yang ditandai dengan keberadaan dan kegiatan partai politik tingkat daerah dan DPRD sebagai mitra pemerintah daerah dalam penyelenggaraan pemerintah daerah, dan di tingkat kampung dapat dilihat dengan dibentuknya Badan Musyawarah Kampung (BAMUSKAM), yang merupakan bukti pelaksanaan Otonomi daerah yang berlangsung dengan baik. 2). Aspek Administrasi/Manajemen Pemerintah. Pemerintah Kabupaten Nabire dalam melaksanakan Otonomi Daerah secara administratif diawali dengan melakukan identifikasi kewenangan pemerintah daerah, penataan kelembagaan, penempatan personil, pengelolaan sumber keuangan daerah, pengelolaan sarana dan prasarana (aset daerah), dan manajemen pelayanan publik.

Tujuan dan Sasaran Dinas Pendapatan Daerah Kabupaten Nabire sebagai berikut :
a) Tujuan
1) Menggali Potensi sumber-sumber PAD
2) Intensifikasi Pajak dan Retribusi Daerah
3) Menyusun Peraturan Bupati
4) Meningkatkan kerjasama antar instansi terkait
5) Meningkatnya kesadaran Wajib Pajak/Wajib Retribusi
6) Meningkatkan kwalitas/kwantitas SDM Aparatur Dispenda
7) Meningkatkan sarana dan prasarana pendukung
8) Penyempurnaan sistem prosedur pelayanan
b) Sasaran
1) Meningkatnya WP Galian Gol. C dan sumbangan pihak Ketiga
2) Meningkatnya WR
3) Meningkatnya jumlah potensi WP/WR
4) Meningkatnya jumlah penetapan pajak/Retribusi
5) Terwujudnya PERBUD.
6) Terlaksananya SK Bupati mengenai PERBUD.
7) Terwujudnya kerjasama /kesepakatan dengan instansi terkait.
8) Terwujudnya kerjasama/kesepakatan pungutan dengan sejumlah desa.
9) Terlaksananya penyuluhan Pajak/ Retribusi pada $10 \mathrm{Kel} \& 10 \mathrm{kampung}$.
10) Terlaksananya pekan panutan Pajak Retribusi 1 kali setahun.

Target dan realisasi Penerimaan Asli Daerah (PAD) Kabupaten Nabire menurut jenis penerimaan pada tiga tahun terkahir ini yaitu pada tahun 2012 sampai dengan tahun 2015 mengalami kenaikan. Hal ini dapat dilihat pada Tabel 4.1.berikut ini. 
Tabel 4.1.Target dan Realisasi Penerimaan Asli Daerah Kabupaten Nabire Tahun 2012 - Tahun 2015

\begin{tabular}{cccc}
\hline Tahun & Target $(\mathrm{Rp})$ & Realisasi $(\mathrm{Rp})$ & Prosentasi $(\%)$ \\
\hline 2012 & 705131463110 & 741046489704 & 105,09 \\
2013 & 781012073059 & 248923194397 & 31,87 \\
2014 & 916349792843 & 1018906530235 & 111,19 \\
2015 & 1047471302157 & 1200853019419 & 114,64 \\
\hline
\end{tabular}

Sumber data : BPS Kabupaten Nabire, 2016

Tabel 4.1. menunjukkan bahwa Penerimaan Asli Daerah Kabupaten Nabire pada empat tahun terakhir potensi $105,09 \%$ pada tahun 2012, namun mengalami penurunan potensi $31 \%$ pada tahun berikutnya 2013, dan kenaikan yang cukup drastis yaitu sebesar $111,19 \%$ pada tahun 2014 dan menjadi 114,64\% pada tahun 2015.

Tabel 4.3 Sistem dan Prosedur Penerimaan Pajak dan Retribusi Daerah Pada Dinas Pendapatan Kab. Nabire, Tahun 2016

\begin{tabular}{|c|c|c|c|}
\hline No & Pelaksanaan & Langkah & Aktivitas \\
\hline 1 & PPKD & 1 & $\begin{array}{l}\text { Menyerahkan SKP yang telah diterbitkan kepada } \\
\text { Bendahara Penerimaan dan melakukan verifikasi } \\
\text { pada saat penerimaan pendapatan. }\end{array}$ \\
\hline \multirow[t]{2}{*}{2} & $\begin{array}{l}\text { Pengguna } \\
\text { Anggaran }\end{array}$ & 2 & $\begin{array}{l}\text { Menyerahkan SKR yang telah diterbitkan kepada } \\
\text { Bendahara Penerimaan pada saat bendahara } \\
\text { penerimaan dan melakukan verifikasi pada saat } \\
\text { penerimaan pendapatan }\end{array}$ \\
\hline & & 3 & $\begin{array}{l}\text { Menerima dan mengesahkan Laporan } \\
\text { Pertanggungjawaban Penerimaan melalui PPK- } \\
\text { SKPD }\end{array}$ \\
\hline 3 & Wajib Pajak & 4 & Menyerahkan uang (setoran pajak/retribusi) \\
\hline 4 & PPK-SKPD & 5 & $\begin{array}{l}\text { Melakukan verifikasi harian atas kas } \\
\text { penerimaan. }\end{array}$ \\
\hline \multirow[t]{5}{*}{5} & \multirow[t]{5}{*}{$\begin{array}{l}\text { Bendahara } \\
\text { Penerimaan }\end{array}$} & 6 & $\begin{array}{l}\text { Melakukan verifikasi penerimaan uang dengan } \\
\text { SKP Daerah/SKR Daerah yang bersangkutan. }\end{array}$ \\
\hline & & 7 & $\begin{array}{l}\text { Mengeluarkan Surat Tanda Bukti } \\
\text { Pembayaran/Bukti Lain yang Sah. }\end{array}$ \\
\hline & & 8 & Menyiapkan STS \\
\hline & & 9 & $\begin{array}{l}\text { Menyiapkan Penyetoran kepada bank disertai } \\
\text { STS }\end{array}$ \\
\hline & & 10 & $\begin{array}{l}\text { STS telah diotorisasikan oleh bank kemudian } \\
\text { diterima kembali oleh Bendahara Penerimaan } \\
\text { untuk kemudian menjadi bukti pembukuan. }\end{array}$ \\
\hline
\end{tabular}

Sumber : Dinas Pendapatan Kabupaten Nabire, Tahun 2016

Tabel 4.2, menunjukkan bahwa sistem dan prosedur penerimaan pada Dinas Pendapatan dilakukan oleh beberapa pelaksana dan dokumen yang digunakan yaitu Surat Ketetapan Pajak Daerah (SKPD) / Surat Ketetapan Retribusi Daerah (SKRD), Surat Tanda Setor (STS), Surat Tanda Bukti Pembayaran (STBP) / Bukti Lain yang Sah.

Hasil penelitian menunjukkan bahwa Dinas Pendapatan Kabupaten Nabire sebagai dinas Pengelolaan Keuangan Daerah telah memiliki sistem dan prosedur penerimaan kas yang 
memadai yang sudah sesuai dengan Permendagri No 59 Tahun 2007Pasal 89 (Dalam Surat Edaran), dapat dilihat pada tabel 3 berikut ini.

Tabel 4.4. Perbandingan antara Permendagri dengan Sistem dan Prosedur Penerimaan Pajak/Retribusi Daerah di Dinas Pendpatan Kabupaten Nabire, Tahun 2016

\begin{tabular}{|c|c|c|c|}
\hline & $\begin{array}{l}\text { Permendagri No 59 Tahun 2007Pasal } 89 \\
\text { (Dalam Surat Edaran) }\end{array}$ & Hasil Penelitian & Ket. \\
\hline $\begin{array}{l}\text { Pihak yang } \\
\text { Terkait }\end{array}$ & $\begin{array}{l}\text { Pihak yang terkait : PPK-SKPD, Pengguna } \\
\text { Anggaran, Bendahara Penerimaan, BUD }\end{array}$ & $\begin{array}{l}\text { Pembagian tugas/fungsi } \\
\text { antara yang menyiapkan dan } \\
\text { yang mencatat dalam hal ini } \\
\text { fungsi penyimpanan oleh } \\
\text { PPK-SKPD, Pengguna } \\
\text { Anggaran, Bendahara } \\
\text { Penerimaan dan Bagian } \\
\text { Pembukuan/Akuntansi }\end{array}$ & Sesuai \\
\hline Aktivitas & $\begin{array}{l}\text { Prosedur penerimaan pajak dan retribusi : } \\
\text { Pangguna Anggaran menyerahkan SKP/SKR, } \\
\text { WP/WR membayarkan sejumlah uang yang } \\
\text { tertera dalam SKP/SKR, Bendahara } \\
\text { Penerimaan memverifikasi jumlah uang } \\
\text { dengan dokumen SKP/SKR dan menerbitkan } \\
\text { STS/Tanda Bukti lain yang sah kepada } \\
\text { WP/WR, dan menyerahkan uang beserta STS } \\
\text { kepada Bank, dan bank mengotorisasi dan } \\
\text { menerbitkan STS dan Nota Kredit kepada } \\
\text { Bendahara Penerimaan, dan } \\
\text { dipertanggungjawabkan ke Bendahara } \\
\text { Umum Daerah. }\end{array}$ & $\begin{array}{l}\text { Dalam Pelaksanaan aktivitas } \\
\text { terdapat prosedur penyetoran } \\
\text { bukti kas masuk (SKP/SKR, } \\
\text { TBP, STS, dan Nota Kredit } \\
\text { Bank) yang dimulai PA, } \\
\text { Wajib Pajak/Wajib Retribusi, } \\
\text { Bendahara Penerimaan dan } \\
\text { selanjutnya uang disetorkan } \\
\text { ke bank. }\end{array}$ & Sesuai \\
\hline Dokumen & $\begin{array}{l}\text { Dokumen yang digunakan yaitu: } \\
\text { 1) Surat Ketetapan Pajak Daerah (SKPD) } \\
\text { 2) Surat Ketetapan Retribusi Daerah } \\
\text { (SKRD) } \\
\text { 3) Surat Tanda Setor (STS) } \\
\text { 4) Nota Kredit Bank/Dokumen atau Bukti } \\
\text { lain yang sah } \\
\text { 5) Surat Tanda Bukti Penerimaan (STBP) }\end{array}$ & $\begin{array}{l}\text { Terdapat dokumen } \\
\text { penyetoran yaitu : } \\
\text { 1) Surat Ketetapan Pajak } \\
\text { Daerah (SKPD) } \\
\text { 2) Surat Ketetapan Retribusi } \\
\text { Daerah (SKRD) } \\
\text { 3) Surat Tanda Setor (STS) } \\
\text { 4) } \text { Nota Kredit } \\
\text { Bank } \\
\text { 5) } \text { Bukti lain } \\
\text { yang sah }\end{array}$ & Sesuai \\
\hline
\end{tabular}

Sumber : Data Hasil Olahan, Tahun 2016

Tabel 4.4, menunjukkan bahwa sistem dan prosedur penerimaan yang dilakukan oleh Dinas Pendapatan Kabupaten Nabire telah sesuai dengan PERMENDAGRI No. 59 Tahun 2007 mulai dari pihak/fungsi yang terkait, aktivitas dan dokumen yang digunakan 
Tabel 4.5 Evaluasi Sistem dan Prosedur Penerimaan Pajak dan Retribusi Daerah pada Dinas Pendapatan Kabupaten Nabire, Tahun 2016

\begin{tabular}{|c|c|c|c|c|}
\hline No & Pelaksanaan & Langkah & Aktivitas & Dokumen \\
\hline 1 & PPKD & 1 & $\begin{array}{l}\text { Menyerahkan SKP yang telah } \\
\text { diterbitkan kepada Bendahara } \\
\text { Penerimaan dan melakukan } \\
\text { verifikasi pada saat penerimaan } \\
\text { pendapatan. }\end{array}$ & $\begin{array}{l}\text { Surat Ketetapan } \\
\text { Pajak Daerah } \\
\text { (SKPD) }\end{array}$ \\
\hline \multirow[t]{2}{*}{2} & \multirow[t]{2}{*}{$\begin{array}{l}\text { Pengguna } \\
\text { Anggaran }\end{array}$} & 2 & $\begin{array}{l}\text { Menyerahkan SKR yang telah } \\
\text { diterbitkan kepada Bendahara } \\
\text { Penerimaan pada saat bendahara } \\
\text { penerimaan dan melakukan } \\
\text { verifikasi pada saat penerimaan } \\
\text { pendapatan }\end{array}$ & $\begin{array}{l}\text { Surat Ketetapan } \\
\text { Retribusi } \\
\text { Daerah (SKRD) }\end{array}$ \\
\hline & & 3 & $\begin{array}{l}\text { Menerima dan mengesahkan } \\
\text { Laporan Pertanggungjawaban } \\
\text { Penerimaan melalui PPK-SKPD }\end{array}$ & $\begin{array}{l}\text { Tanda Bukti } \\
\text { Penerimaan } \\
(\mathrm{TBP})\end{array}$ \\
\hline 3 & Wajib Pajak & 4 & $\begin{array}{l}\text { Menyerahkan uang (setoran } \\
\text { pajak/retribusi) }\end{array}$ & $\begin{array}{l}\text { Surat Tanda } \\
\text { Setor (STS) }\end{array}$ \\
\hline 4 & PPK-SKPD & 5 & $\begin{array}{l}\text { Melakukan verifikasi harian atas } \\
\text { kas penerimaan. }\end{array}$ & $\begin{array}{l}\text { Surat Ketetapan } \\
\text { Pajak Daerah } \\
\text { (SKPD) / SKR } \\
\text { dan STS }\end{array}$ \\
\hline \multirow[t]{4}{*}{5} & \multirow[t]{4}{*}{$\begin{array}{l}\text { Bendahara } \\
\text { Penerimaan }\end{array}$} & 6 & $\begin{array}{l}\text { Melakukan verifikasi penerimaan } \\
\text { uang dengan SKP Daerah/SKR } \\
\text { Daerah yang bersangkutan. }\end{array}$ & $\begin{array}{l}\text { Tanda Bukti } \\
\text { Penerimaan } \\
\text { (TBP) }\end{array}$ \\
\hline & & 7 & $\begin{array}{l}\text { Mengeluarkan Surat Tanda Bukti } \\
\text { Pembayaran/Bukti Lain yang Sah. }\end{array}$ & $\begin{array}{l}\text { Tanda Bukti } \\
\text { Penerimaan } \\
\text { (TBP }\end{array}$ \\
\hline & & 8 & $\begin{array}{l}\text { Menyiapkan Penyetoran kepada } \\
\text { bank disertai STS }\end{array}$ & $\begin{array}{l}\text { Nota Kredit } \\
\text { Bank (Bukti } \\
\text { Slip dari Bank) }\end{array}$ \\
\hline & & 9 & $\begin{array}{l}\text { STS telah diotorisasikan oleh bank } \\
\text { kemudian diterima kembali oleh } \\
\text { Bendahara Penerimaan untuk } \\
\text { kemudian menjadi bukti } \\
\text { pembukuan. }\end{array}$ & $\begin{array}{l}\text { Tanda Bukti } \\
\text { Penerimaan } \\
\text { (TBP) }\end{array}$ \\
\hline
\end{tabular}

Sumber : Dinas Pendapatan Kabupaten Nabire, Tahun 2016

Tabel 4.5 menunjukkan bahwa evaluasi sistem dan prosedur penerimaan sudah sesuai dengan fungsi saat pencatatan, penyimpanan dan yang mengotorisasi semua yyang terkait dengan penerimaan dan penyetoran Pendapatan Daerah melalui bendahara penerimaan. Dokumen tersebut di buat beberapa rangkap untuk diserahkan kepada WP/WR yang akan membayar pajak/retribusi yang disertai dengan STS dua rangkap yang nantinya akan menjadi bukti telah melakukan penyetoran uang ke rekening kas Umum Daerah (Bank). 
Tabel 4.6. Evaluasi Perbandingan antara Permendagri dengan Sistem dan Prosedur Penerimaan Pajak/Retribusi Daerah di Dinas Pendpatan Kabupaten Nabire

\begin{tabular}{|l|l|l|c|}
\hline No & $\begin{array}{c}\text { Permendagri 59 Tahun } \\
\text { 2007Pasal 89 } \\
\text { (Dalam Surat Edaran) }\end{array}$ & \multicolumn{1}{|c|}{ Hasil Penelitian } & Ket. \\
\hline 1 & Pihak/Fungsi Terkait & $\begin{array}{l}\text { Pembagian tugas/fungsi antara yang menyiapkan } \\
\text { dan yang mencatat dalam hal ini fungsi } \\
\text { penyimpanan oleh PPK-SKPD, PA, Bendahara } \\
\text { Penerimaan dan Bagian Pembukuan/Akuntansi }\end{array}$ & Sesuai \\
\hline 2 & Aktivitas & $\begin{array}{l}\text { Dalam Pelaksanaan aktivitas terdapat prosedur } \\
\text { penyetoran bukti kas masuk (SKP/SKR, TBP, STS, } \\
\text { dan Nota Kredit Bank) yang dimulai PA, Wajib } \\
\text { Pajak/Wajib Retribusi, Bendahara Penerimaan dan } \\
\text { selanjutnya uang disetorkan ke bank. }\end{array}$ & Sesuai \\
\hline 3 & Dokumen & $\begin{array}{l}\text { Terdapat dokumen penyetoran yaitu : } \\
\text { 1) Surat Ketetapan Pajak Daerah (SKPD) } \\
\text { 2) Surat Ketetapan Retribusi Daerah (SKRD) } \\
\text { Surat Tanda Setor (STS) } \\
\text { Nota Kredit Bank }\end{array}$ & Sesuai \\
\hline
\end{tabular}

Sumber : Data Hasil Olahan

Tabel 4.6, menunjukkan bahwa sistem dan prosedur penerimaan yang dilakukan oleh Dinas Pendapatan Kabupaten Nabire telah sesuai dengan PERMENDAGRI No. 59 Tahun 2007 mulai dari pihak/fungsi yang terkait, aktivitas dan dokumen yang digunakan.

\section{KESIMPULAN DAN SARAN}

\subsection{Kesimpulan}

Berdasarkan penelitian dan pembahasan yang dilakukan maka dapat disimpulkan sebagai berikut :

1) Sistem dan prosedur penerimaan pada Dinas Pendapatan Kabupaten Nabire telah dilakukan sesuai dengan Undang-Undang Nomor 16 tahun 2000 tentang Ketentuan Umum dan Tata Cara Perpajakan dimana wajib pajak mempunyai kewajiban menjadi seorang wajib pajak sesuai dengan prosedur yang ditetapkan, selain itu juga hasil penelitian menunjukkan adanya penerapan PERMENDAGRI No. 59 Tahun 2007 yang mencakup fungsi yang terkait, aktivitas dan dokumen yang digunakan pada sistem dan prosedur sistem penerimaan kas dengan baik pada daerah penelitian.

2) Sistem pemungutan pajak yang dilakukan oleh Dinas Pendapatan Daerah Kabupaten Nabire adalah sistem Self assessment yang memberikan wewenang kepada wajib pajak untuk menentukan sendiri besarnya pajak yang terutang.

\subsection{Saran}

Dari hasil uraian pembahasan dan kesimpulan sebagaimana dijelaskan diatas, maka penulisan dapat menyampaikan saran sebagai berikut :

1) Pihak Dinas Pendapatan Kab. Nabire, sebaiknya memperhatikan lebih rinci dalam melaksanakan sistem dan prosedur dalam mengelola keuangan daerah. Khususnya pada bagian pembukuan/akuntansi dalam rangka pengimplementasian prosedur pembukuan khususnya dalam penjurnalan sesuai fungsinya.

2) Dalam pelaksanaan pengendalian intern sudah berjalan dengan baik, hanya saja harus diadakan sosialisasi dan bimbingan teknis bagi para pegawai khususnya di bidang akuntansi agar pelaksanaanya menjadi lebih baik. 


\section{DAFTAR PUSTAKA}

Beni Pekei. 2016. Konsep dan Analisis Efektivitas Pengelolaan Keuangan Daerah di Era Otonomi. Jakarta. Penerbit Taushia

Edogbanya, 2013. Revenue Generation : It's Impact on Government Developmental Effort ( A Study of Selected Local Council in Kogi East Senatorial District). Kogi State University. Nigeria. Global Journals Inc. Vol 13. Issue 4 (2013)

Hariadi Purnomo, Restianto Yanuar E \& Bawono, Icuk Rangga. 2010. Pengelolaan Keuangan Daerah. Penerbit Salembe Empat. jakarta

Hidayah, Nurul. 2010. Akuntansi Sektor Publik Pemerintahan dan Swasta. Penerbit Modul Universitas Mercu Buana. Jakarta

Ibrahim. 2015. Metodologi Penelitian Kualitatif ; Panduan Penelitian beserta Contoh Proposal Kualitatif. Bandung. Penerbit Alfabeta

Karamoy, Rone. 2013. Evaluasi Pelaksanaan Sistem dan Prosedur Penerimaan Kas pada Dinas Pendapatan Kota Manado. Universitas Sam Ratulangi. Manado. Jurnal EMBA. Vol 1. No 3 (2013).

Mahmudi. 2013. Akuntansi Sektor Publik. Yogyakarta.UII Press

Mahsun, Firma, Purwanugraha. 2015. Akuntansi Sektor Publik. Yogyakarta. Penerbit BPFE Mardiasmo. 2016. Perpajakan Edisi Terbaru 2016. Yogyakarta. Penerbit ANDI OFFSET

Peraturan Menteri Dalam Negeri No. 13 Tahun 2006 tentang Pedoman Pengelolaan Keuangan Daerah

Priyati, Novi. 2013. Pengantar Akuntansi. Jakarta. Penerbit Erlangga

Ratmono, Dr. Dwi dan Mahfud Sholihin. 2015. Akuntansi Keuangan Daerah Berbasis Akrual. Penerbit UPP STIM YKPN. Yogyakarta

Riyanto, Agus Puji. 2015. Akuntansi Pemerintah Daerah Berbasis Akrual. Penerbit Pustaka Belajar. Yogyakarta

Republik Indonesia, Peraturan Pemerintah Nomor 52 Tahun 1996 TentangPembentukan Kabupaten Puncak Jaya, Kabupaten Paniai Perubahan Nama dan Pemindahan Ibukota Kabupaten Daerah Tingkat II Paniai di Wilayah Propinsi Daerah Tingkat I Irian Jaya.

Daerah.

1999. Undang-Undang No. 22 Tahun 1999 Tentang Pemerintah . 1999. Undang-Undang No. 25 Tahun 1999 Tentang Perimbangan Keuangan Antara Pusat dan Daerah.

Retribusi Daerah 2000. Undang-Undang No. 34 Tahun 2000 Tentang Pajak dan 2000. Undang-Undang No. 65 Tahun 2000 Tentang Pajak Daerah . 2000. Undang-Undang No. 66 Tahun 2000 Tentang Retribusi Daerah 2002. Keputusan Menteri Dalam Negeri No. 29 Tahun 2002 Tentang

Pedoman Pengurusan, Pertanggungjawaban dan Pengawasan Keuangan Daerah serta Tata Cara Penyusunan Anggaran Pendapatan dan Belanja Daerah, Pelaksanaan Tata Usaha Keuangan Daerah dan Penyusunan Perhitungan Anggaran Pendapatan dan Belanja Daerah. Jakarta . 2003. Undang-Undang No. 17 Tahun 2003 Tentang Keuangan Negara. 2004. Undang-Undang No. 15 Tahun 2004 Tentang Perbendaharaan

Negara

Daerah 2004. Undang-Undang No. 32 Tahun 2004 Tentang Pemerintah 2004. Undang-Undang No. 33 Tahun 2004 Tentang Perimbangan Keuangan antara Pusat dan Daerah 
Keuangan Daerah

2005. Peraturan Pemerintah No. 58 Tahun 2005 Tentang Pengelolaan

. 2006. Peraturan Menteri Dalam Negeri No. 13 Tahun 2006 Tentang Pedoman Pengelolaan Daerah 2007. Peraturan Menteri Dalam Negeri No. 59 Tahun 2007 Tentang Pedoman Pengelolaan Keuangan Daerah

. 2008. Peraturan Pemerintah No. 60 Tahun 2008 Tentang Sistem Pengendalian Intern Pemerintah.

Retribusi Daerah

2009. Undang-Undang No. 28 Tahun 2009 Tentang Pajak Daerah dan

2010. Peraturan Pemerintah No. 71 Tahun 2010 Tentang Standar Akuntansi Pemerintah

Daerah.

2014. Undang-Undang No. 23 Tahun 2014 Tentang Pemerintahan

Siregar, Dr.Baldric. 2015. Akuntansi Sektor Publik (Akuntansi keuangan Pemerintah daerah Berbasis Akrual). Penerbit UPP STIM YKPN. Yogyakarta

Sujarweni, V. Wiratna. 2015. Akuntansi Sektor Publik. Penerbit Pustaka Baru Press. Yogyakarta

Sujarweni, V. Wiratna. 2014. Metodologi Penelitian. Penerbit Pustaka Baru Press. Yogyakarta

Surat Edaran Menteri Dalam Negeri BAKD. 2009. Sistem dan Prosedur Pengelolaan Keuangan Daerah.

Sondakh Jullie, Harijanto Sabijono, dan Raisa Janis. 2015. Analisis Sistem dan Prosedur Penerimaan PAD pada Dinas Pendapatan Pengelolaan Keuangan dan Aset Daerah Kabupaten Sitaro. Universitas Sam Ratulangi. Manado.

https://scholar.google.co.id/scholar?hl=id\&as_sdt=0\%2C5\&q=analisis + sistem + dan + prosedur+penerimaan + pada + Dinas + Pendapatan + Pengelolaan + keuangan + dan + aset + daerah + kabupaten + sitaro \&btnG $=$. Diakses pada 30 September 2017

Http://www.kajianpustaka.com/2015/06/pendapatan-asli-daerah-pad.html

Http://www.landasanteori.com/2015/07/pengertian-pendapatan-asli-daerah-dan-html

Http://primalifejournal.wordpress.com/2013/03/26/pendapatan-asli-daerah-pad/

http://www.landasanteori.com/2015/10/pengertian-dana-alokasi-umum-definisi.html. 